\title{
Ethyl acetate fraction of Psorospermum febrifugum Spach aqueous extract did not exhibit acute or sub-chronic toxicity. Experimental study on Wistar rats
}

\author{
Agbogba $\mathrm{F}^{1}$, Sènou $\mathrm{M}^{2}$, Tchogou $\mathrm{AP}^{2,3}$, Lokonon $\mathrm{JE}^{2}$, Sacramento $\mathrm{TI}^{1}$, Medoatinsa $\mathrm{E}^{2}$, Kanfon $\mathrm{RE}^{4}$, Atakpa E ${ }^{1}$, \\ Dougnon $\mathrm{TV}^{3}$, Agbangnan $\mathrm{DCP}^{4}$, Loko $\mathrm{F}^{3}$, Lalèyè $\mathrm{A}^{5}$, Atègbo $\mathrm{JM}^{1}$, Baba-Moussa $\mathrm{SL}^{6}$, Agbonon $\mathrm{A}^{7}$ \& Sèzan $\mathrm{A}^{1}$. \\ ${ }^{1}$ Laboratory of Biomembrane and Cell Signaling, Faculty of Sciences and Techniques, University of \\ Abomey-Calavi, R Benin. \\ ${ }^{2}$ Experimental and Clinic Biology Laboratory, National School of Applied Biosciences and Biotechnology, \\ National University of Science, Technology, Engineering and Mathematics (UNSTIM), Dassa-Zoumé, R. Benin. \\ ${ }^{3}$ Research Laboratory in Applied Biology, Polytechnic School of Abomey-Calavi, University of Abomey-Calavi, \\ Cotonou, R. Benin. \\ ${ }^{4}$ Laboratory of Study and Research in Applied Chemistry, Polytechnic School of Abomey-Calavi, University of \\ Abomey-Calavi, R. Benin. \\ ${ }^{5}$ Human Biology Unit, Faculty of Health Science, Cotonou, R. Benin. \\ ${ }^{6}$ Laboratoire de Biologie et de Typage Moléculaire en Microbiologie, University of Abomey-Calavi R. Benin. \\ ${ }^{7}$ Laboratoire de Physiologie/Pharmacologie, Faculté des Sciences, Université de Lomé, R. Togo. \\ Correspondence: Sènou M, Experimental and Clinic Biology Laboratory, National School of Applied \\ Biosciences and Biotechnology, National University of Science, Technology, Engineering and Mathematics \\ (UNSTIM), Dassa-Zoumé, R. Benin. Tel: 22997265827. E-mail: senouxim@yahoo.fr
}

Received: August 29, 2019

doi:10.5539/ijb.v11n4p123
Accepted: September 19, 2019 Online Published: September 30, 2019

URL: https://doi.org/10.5539/ijb.v11n4p123

\begin{abstract}
Psorospermum febrifugum Spach (Clusiaceae) was a tropical plant whose root bark was used to treat anemia. This work aimed to evaluate the safety of the ethyl acetate fraction of the aqueous extract of this bark. Methods: The ethyl acetate fraction of the extract was administered to Wistar rats in a single dose of $2000 \mathrm{mg} / \mathrm{Kg}$ body weight for acute oral toxicity test or daily doses of $200 \mathrm{mg} / \mathrm{Kg}$ of body weight during 28 days for sub-chronic oral toxicity test, as recommended by the OECD. At day 0 , then at day 14 for the acute phase and day 28 for the sub-chronic phase, the rats were weighed and their blood collected for tests. The activity of transaminases AST and ALT were measured in the liver function tests, blood urea and creatinine were measured for renal function tests and blood leukocytes were counted for the immune balance. These analyzes were supplemented by the histology of the liver, kidneys and spleen, an immune organ. Results: In acute and sub-chronic oral toxicity tests, rat's weight, liver, kidney and immune balances as well as these organs histology were not affected, suggesting the safety of the extract fraction. Conclusion: The ethyl acetate fraction of the aqueous extract of the root bark of Psorospermum febrifugum did not reveal any acute or sub-chronic oral toxicity. This effect could be related to its richness in flavonoids which have cytoprotective effects. The study of biological tolerance deserves to be continued by the chronic toxicity test and appropriate clinical trials.
\end{abstract}

Keywords: Psorospermum febrifugum, fractionation, biological tolerance

\section{Introduction}

Medicinal plants were used by different populations for centuries around the world to deal with health problems (Kassel, 2003). Thus, $80 \%$ of people in poor countries use traditional medicine. The main reason was the high price of pharmaceutical drugs (Schmincke, 2003; Yakubu et al., 2009; Pingali et al., 2015). Therefore, many plants are used against anemia, some of which are very effective. That were the cases of Maguifera indica leaves and stem (Ogbe et al., 2010), Schrebera swietenioides root bark (Pingali et al., 2015), Moringa oleifera leaves (Nwaehujor et al., 2015) and Cocos nucifera root bark (Tchogou et al., 2016). 
Very little is known about the effects of medicinal remedies used against various pathologies (Oduola et al., 2007). This raises the question of the safety of these substances. Phytochemical screening of several plants revealed the presence of toxic molecules (Oduola et al., 2007). Also, side effects on different organs have been noted as a result of the consumption of traditional remedies. Renal damage has been associated with the use of the medicinal plants in the treatment of different disorders, including diabetes mellitus (Mapanga \& Musabayane, 2010). So toxicity of herbal medicines needs attention in order to prevent side effects (Haq, 2004; Philomena, 2011; Nasri, 2013). WHO encouraged scientific investigations in this area to select the best ones for beneficial use.

Psorospermum febrifugum Spach is widely used in traditional medicine in Africa. It grows in savannas and tropical ears and belongs the family of Hypericaceae (Arbonnier, 2000). The aqueous extract of it root bark effectively treats anemia (Agbogba et al., 2019a). This extract was not also toxic (Agbogba et al., 2019b). The aim of the present study was to test the safety of the aqueous extract ethyl acetate fraction of this root bark in an experimental animal model.

\section{Material and Methods}

\subsection{Animal Material}

Animal material consisted of Wistar albino rats of average body weight $173 \mathrm{~g}$ approximately, having free access to water and food and acclimated to farming conditions from the pet of the Biomembrane and Cell Signaling Laboratory in Faculty of Sciences and Techniques of the University of Abomey-Calavi (UAC) in Benin Republic. Breeding was done in a well ventilated room, with a day-night rhythm of $12 \mathrm{~h}$. The animals were kept in wire mesh cages with metal feeders and drinking troughs. Their daily diet was made from a mixture of food in the form of croquettes and marketed by Vet Services (Benin). The enclosure was regularly cleaned to ensure optimal development of the animals avoid infection.

\subsection{Identification and Preparation of Plant Material}

\subsubsection{Identification}

Psorospermum febrifugum Spach (Clusiaceae) roots bark was collected from Atlantic Department in Benin during April 2015. The collected samples were identified and certified at the National Herbarium of the University of Abomey Calavi under the number AA6625 / HNB. The samples were dried at moderate temperatures (20-250 C), protected from moisture for four weeks. They were then crushed into powder and stored in suitable containers at room temperature.

\subsubsection{Preparation of the Aqueous Extract}

$50 \mathrm{~g}$ of root powder of Psorospermum febrifugum Spach (Clusiaceae) roots bark were boiled in $500 \mathrm{ml}$ of distilled water in a $1000 \mathrm{ml}$ flask for 30 minutes. After cooling, the mixture was filtered using the Bushner. This operation was repeated for six times for a total mass of $300 \mathrm{~g}$. The filtrate (the aqueous phase) obtained was recovered and stored in a refrigerator in a jar for liquid-liquid extraction (first fractionation step).

\subsubsection{Fractionation of the Extract}

Liquid-liquid extraction consists in passing a substance from a solvent, from which it wass often difficult to separate, to another (called extraction solvent), from which it would be easily isolable. This operation, usually carried out by stirring, was possible provided that the two solvents were very little or no miscible with one another. But extraction was never $100 \%$, there were always molecules of the compound to be extracted in the solvent in which it was less soluble.

The Liquid-liquid was obtained by successive partitions with solvents of increasing polarity (hexane and ethyl acetate) according to the protocol of Koudoro et al. (2014).

In a separatory funnel, was added to the aqueous extract solution the appropriate volume of extraction solvent. After vigorous agitation, the mixture was allowed to settle. After decantation, the two phases were separated by collecting the lower phase (aqueous phase) in a flask and the upper phase (organic phase) in another. The aqueous phase was re-poured into the separating funnel before repeating the following steps. After each extraction step, the organic phases were combined, which constituted the fraction in a jar.

The liquid-liquid extracts obtained was then evaporated using a rotary evaporator at a temperature according to the solvents of polarity. The extractant phase was re-sealed and solidified in an oven at $40^{\circ} \mathrm{C}$. The dry residue obtained was reduced to powder and stored in a refrigerator in a brown flask. The yield of the fraction was calculated by the following formula: 


$$
\mathrm{R}=\frac{\text { Mass of fraction }}{\text { Mass of powder }} \times 100
$$

\subsection{Acute Toxicity Test}

Acute toxicity test was carried out as recommended by the guideline 423 of the Organization for Economic Cooperation and Development for the testing of chemicals (OECD, 2002).

The substance was tested in a sequential process in which three animals including multiparous females and no pregnant aged 8 to 12 weeks are used at each stage. The absence or the manifestation of substance related mortality in a group dosed at a step would determine the next step. The initial dose was selected from the following four doses: 5, 50,300 and $2000 \mathrm{mg} / \mathrm{kg}$ body weight. We administered by gavage to animals $2000 \mathrm{mg}$ of Psorospermum febrifugum Spach (Clusiaceae) roots bark ethyl acetate extract fraction $/ \mathrm{kg}$ body weight. The animals were observed carefully during the four (4) hours and then daily for 14 days. They were weighed and blood was collected by orbital puncture at the start of the experiment and then after 14 days.

\subsection{Sub-chronic Toxicity Tests}

Five Wistar rats received the Psorospermum febrifugum Spach (Clusiaceae) roots bark ethyl acetate extract fraction at $200 \mathrm{mg} / \mathrm{kg}$ body weight, daily for 28 consecutive days by gavage (Biswas et al., 2010). They were weighed and blood was collected by orbital puncture at the start of the experiment and then after 28 days.

\subsection{Blood Tests}

Biochemical parameters such as uremia and serum creatinine were doses to explore renal function. Transaminases AST and ALT were assayed for liver function. The WBC count was performed as hematological parameter.

\subsection{Histology}

At the end of the experiment, the animals were dissected. The liver, the kidney and the spleen were removed, fixed in Bouin solution, and embedded in paraffin. The specimens sections $(5 \mu \mathrm{m})$ were mounted on glass slides, deparaffinated, and hydrated. For histological analysis, sections were stained with hematoxylin and eosin (H\&E), following a standard protocol (Sènou et al., 2010). The pictures were taken at 400X magnification.

\subsection{Statistical Analysis}

The means were compared using Mann-Whitney test. The significance level was set at 5\%.

\section{Results}

3.1 The Ethyl Acetate Fraction of Psorospermum febrifugum Root Bark Aqueous Extract Was Not Toxic in Acute Toxicity Test

The acute oral toxicity was assessed by measuring the physical parameter that is the weight of the rats, the liver function through the transaminases ALT and AST, renal balance through blood urea and creatinine, the immune balance by counting the blood leucocytes (Table 1).

Table 1. Acute oral toxicity test

\begin{tabular}{lllll}
\hline Parameters & Means at D0 & Means at D14 & Pvalue & Difference \\
\hline Rat weight (g) & $173 \pm 13$ & $179 \pm 8$ & 0.5 & no significant \\
Uremia $(\mathrm{g} / \mathrm{L})$ & $0.40 \pm 0.11$ & $0.43 \pm 0.13$ & 0.9 & no significant \\
Creatinine (mg/L) & $10 \pm 2$ & $10 \pm 3$ & 0.8 & no significant \\
Transaminase AST (IU/L) & $100 \pm 11$ & $105 \pm 11$ & 0.7 & no significant \\
Transaminase ALT (IU/L) & $58 \pm 14$ & $62 \pm 14$ & 0.8 & no significant \\
White Blood Cells (G/L) & $7.2 \pm 1.2$ & $7.8 \pm 1.4$ & 0.5 & no significant \\
\hline
\end{tabular}

The mean weight of the rats at day 0 was $173 \pm 13 \mathrm{~g}$ and did not significantly change at day 14 , suggesting no disturbance of the physical parameters of the test rats.

Uremia and serum creatinine at D0 were $0.40 \pm 0.11 \mathrm{~g} / \mathrm{L}$ and $10 \pm 2 \mathrm{mg} / \mathrm{L}$, respectively. They did not significantly change values at day 14 suggesting a lack of renal function impairment.

Transaminases AST and ALT were on D0 respectively $100 \pm 11 \mathrm{IU} / \mathrm{L}$ and $58 \pm 14 \mathrm{IU} / \mathrm{L}$. They did not significantly increase on Day 14 indicating no disturbance of liver function. 
The leukocyte count at D0 was $7.2 \pm 1.2 \mathrm{G} / \mathrm{L}$ and did not significantly increase at D14 suggesting an absence of immune disturbance.

\subsection{The Ethyl Acetate Fraction of Psorospermum febrifugum Root Bark Aqueous Extract Was Not Toxic in Sub-chronic Toxicity Test}

Parameters taken into account for acute oral toxicity were also evaluated for the subchronic oral toxicity test. Those were rat weight, transaminases, and uremia, creatinine and white blood cell counts (Table 2).

Table 2. Subchronic toxicity test

\begin{tabular}{lllll}
\hline Parameters & Means at D0 & Means at D28 & Pvalue & Difference \\
\hline Rat weight (g) & $174 \pm 10$ & $182 \pm 17$ & 0.7 & no significant \\
Uremia (g/L) & $0,40 \pm 0.11$ & $0.47 \pm 0.17$ & 0.8 & no significant \\
Creatinine (mg/L) & $8 \pm 2$ & $9 \pm 2$ & 0.9 & no significant \\
Transaminase AST (IU/L) & $114 \pm 17$ & $122 \pm 20$ & 0.7 & no significant \\
Transaminase ALT (IU/L) & $59 \pm 10$ & $57 \pm 14$ & 0.9 & no significant \\
White Blood Cells (G/L) & $7.3 \pm 1.1$ & $8.1 \pm 1.2$ & 0.5 & no significant \\
\hline
\end{tabular}

The mean weight of rats at day 0 was $174 \pm 10 \mathrm{~g}$. It increased slightly at D28, but the increase was not significant suggesting an absence of physical alteration. Uremia and serum creatinine at day 0 were $0.40 \pm 0.11$ $\mathrm{g} / \mathrm{L}$ and $8 \pm 2 \mathrm{mg} / \mathrm{L}$, respectively. Their values did not significantly change on D28 indicating a preservation of renal function. Transaminases AST and ALT respective values $114 \pm 17 \mathrm{UI} / \mathrm{L}$ and $59 \pm 10 \mathrm{IU} / \mathrm{L}$ were not significantly modified at D28 indicating a preservation of liver function. The number of blood leukocytes from $7.3 \pm 1.1 \mathrm{G} / \mathrm{L}$ at day 0 did not significantly change at day 28 suggesting an absence of immune disturbance.

\subsection{The Ethyl Acetate Fraction of the Aqueous Extract of Psorospermum febrifugum Root Bark did not Alter the} Hepatic, Renal and Splenic Parenchyma in the Acute or Sub-chronic Tests

In the acute (Figure 1B) and sub-chronic (Figure 1C) oral toxicity tests, the liver parenchyma was typical as in the control rats (Figure 1A). Hepatocytes (arrows) without visible atypia were ordered in more less radial radius around the central veins $(\mathrm{V})$. The sinusoids $(\mathrm{S})$ were clearly visible between the hepatocytes.

Similarly, the renal parenchyma did not show any visible impairment in the acute (Figure 1E) and sub-chronic (Figure 1F) toxicity tests. As in the control rats (Figure 1D), the glomeruli $(\mathrm{G})$, the proximal tubes (PT), the distal tubes (DT) and collecting ducts (CD) displayed the characteristic appearance.

That was the same for the splenic parenchyma which was not activated in acute (Figure 1H) and sub-chronic (Figure 1I) oral toxicity tests. As in the control rats (Figure 1G), the periarteriolar sheaths (AS) of lymphocytes around the central arteries (CA) and the germinal centers (GC) of the white pulp displayed the typical appearance. It is the same for the sinusoids (S) and the Billroth cords of the red pulp.

\section{Discussion}

Psorospermum febrifugum Spach (Clusiaceae) is a tropical plant whose root bark effectively treats anemia (Agbogba et al., 2019a). In a previous study, we shown that the aqueous extract of these root barks were not toxic in the acute and sub-chronic state (Agbogba et al., 2019b). The phytochemical screening of the extract, having revealed the presence of several families of chemical compounds, it was interesting to target the family groups of compounds that carried the erythropoietic activity. For this purpose, we fractionated the extract in order to test some of its fractions. One of the fractions that we wanted to test was that of ethyl acetate because this fraction of the aqueous extract of Cocos nucifera showed a good hematopoietic activity (Sènou et al., 2017a). But first, it should first ensure the safety of this fraction of the extract before testing its efficacy. For this perspective, the present work objective was to study the safety of the ethyl acetate fraction of Psorospermum febrifugum root bark to ensure first of its biological tolerance. Thus, the acute and sub-chronic oral toxicity tests for this fraction of extract were carried out following the recommendations of the OECD (2002). The analyzed parameters were the weight of the rats, the hepatic, renal and immune balance as well as the histology of these organs.

The ethyl acetate fraction did not change the weight of the rats in the acute and sub-chronic toxicity tests. This observation was also made with the crude extract of this bark (Agbogba et al., 2019b) and with the liquid of the green shell of coconut or its butanoic extract (Costa et al., 2011). 

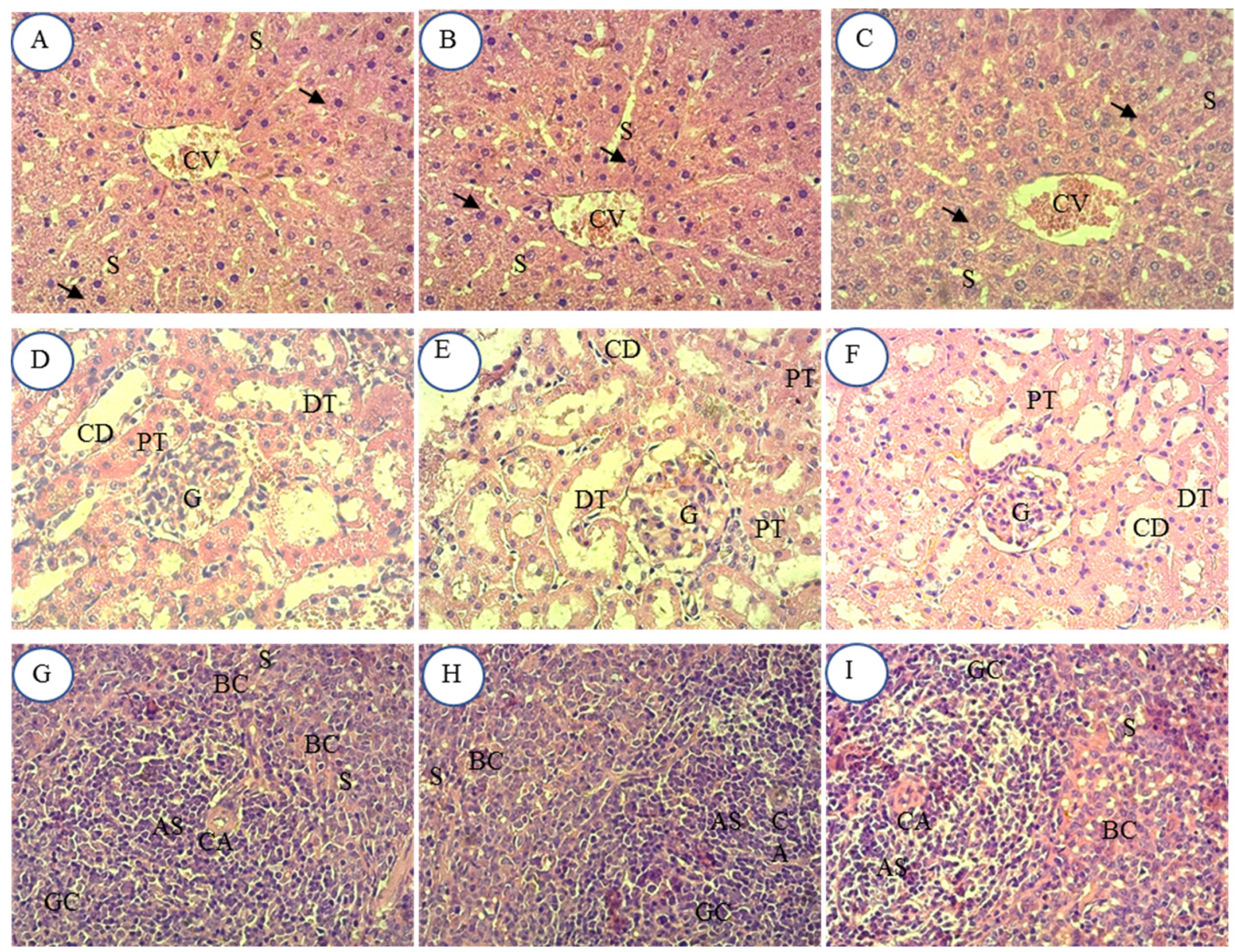

Magnification: $400 \mathrm{X}$

Figure 1. Hepatic, renal and splenic histology of rats in acute and sub-chronic toxicity tests

Liver: $\quad$ controls (A); acute toxicity test (B); sub-chronic toxicity test (C).

Hepatocyte (arrow); central vein (V); sinusoids (S).

Kidney: controls (D); acute toxicity test (E); sub-chronic toxicity test (F).

Glomerulus (G), proximal tubule (PT), distal tubule (TD) and collecting duct (CD).

Spleen: controls $(\mathrm{G})$; acute toxicity test $(\mathrm{H})$; sub-chronic toxicity test (I).

Central artery (CA), peri arteriolar sheaths (AS), germinal center (GC), venous sinusoids (S); Billroth cords (BC).

Liver function balance for acute and sub-chronic oral toxicity tests did not reveal any abnormalities. The AST and ALT transaminases were not increased, indicating an absence of hepatic cytolysis and the hepatic parenchyma did not show atypia. This observation was also made with the crude extract of this bark (Agbogba et al., 2019b). Similar observations were also made with the aqueous extract of the leaf sheath of Sorghum bicolor which also showed a hepatoprotective effect (Sènou et al., 2016).

The renal balance was not changed in the acute and sub-chronic oral toxicity tests. Uremia and serum creatinine did not increase, indicating a lack of nephrotoxicity in the extract fraction, confirmed by renal parenchyma appearance with typical glomeruli, proximal tubes, distal tubes, and collecting ducts. The same observations were made with the crude extract of this bark (Agbogba et al., 2019b). A nephroprotective effect was observed with Coco nucifera water, which lowered uremia and creatinine in a model of ethylene glycol-induced nephropathy (Gandhi et al., 2013). 
The immune balance also showed no abnormality in the acute and sub-chronic oral toxicity tests. The number of blood leukocytes did significantly change and the architecture of the spleen, peripheral immune organ also did not modify. The same observation was made with the crude extract (Agbogba et al., 2019b) and with the ethyl acetate fraction of Cocos nucifera root barks aqueous extract (Sènou et al., 2017b). In addition, an anti-inflammatory effect was noted with the ethyl acetate extract of Cocos nucifera fiber following a local induction of xylene inflammation in animal experiments (Silva et al., 2009).

Ethyl acetate mainly isolated flavonoids (Manjusha et al., 2013, Koudoro et al., 2014) and this group was present in the crude extract (Agbogba et al., 2019a). The absence of toxicity of this extract fraction could be linked to the cytoprotective effect for several members of this family (Fang et al., 2016).

\section{Conclusion}

The study of the ethyl acetate fraction of Psorospermum febrifugum root bark aqueous extract did not reveal any acute or sub-chronic oral toxicity. Hepatic, renal and immune balances were normal. However, the study of biological tolerance deserves to be continued by chronic toxicity test and clinical trials.

\section{References}

Agbogba, F., Sacramento, T. I., Tchogou, A. P., Medoatinsa, E., Kanfon, E. R., Atakpa, E., ... Sèzan, A. (2019a). The aqueous extract of the root bark of Psorospermum febrifugum Spach effectively corrects anaemia. Experimental study on Wistar rats. Journal of Applied Biosciences, 139, https://dx.doi.org/10.4314/jab.v139i1.1

Agbogba, F., Sènou, M., Tchogou, A.P., Sacramento, T.I., Medoatinsa, E., Kanfon, R.E., ... Sèzan, A. (2019b). Study of toxicity of aqueous extract of Psorospermum febrifugum Spach root bark on Wistar rats. International Journal of Biosciences, 14(5), 475-482. http://dx.doi.org/10.12692/ijb/14.5.475-482

An, F., Wang, S., Yuan, D., Gong, Y., \& Wang, S. (2016). Attenuation of oxidative stress of erythrocytes by plant-derived flavonoids, orientin and luteolin. Evidence-Based Complementary and Alternative Medicine, 2016. http://dx.doi.org/10.1155/2016/3401269

Arbonnier, M. (2000). Arbres, arbustes et lianes des zones sèches d'Afrique de l'Ouest. Centre de coopération internationale en recherche agronomique pour le développement, Union internationale pour la conservation de la nature, $\mathrm{p}$ 541. Retrieved from http://publications.cirad.fr/une_notice.php?dk=548 725

Biswas, M., Kar, B., Karan, T. K., Bhattacharya, S., Kumar, R. S., Ghosh, A. K., \& Haldar, P. K. (2010). Acute and sub-chronic toxicity study of Dregea volubilis fruit in mice. Journal of Phytology, 2(8), 6-10.

Costa, C. T. C., Bevilaqua, C. M. L., Do Nascimento, N. R. F., \& Nunes-Pinheiro, D. C. S. (2011). Toxicological activity evaluation of Cocos nucifera L. in experimental models. Ciência Animal, 21(1), 35-44.

Gandhi, M., Aggarwal, M., Puri S., \& Singla S.K. (2013). Prophylactic effect of coconut water (Cocos nucifera L.) on ethylene glycol induced nephrocalcinosis in male wistar rat. Int Braz J Urol, 39, 108-117. http://dx.doi.org/10.1590/S1677-5538.IBJU.2013.01.14

Haq, I. (2004). Safety of medicinal plants Pakistan. Journal of Medical Research, 43(4), 203-210.

Kassel, D. (2003). Des hommes et des plantes. In Histoire de la pharmacie, Décembre 2003, p 88. Retrieved from http://ordre.pharmacien.fr.

Koudoro, Y.A., Dedomè, L.S.O., Yovo, M., Agbangnan-Dossa, C.P., Tchobo, P.F., Alitonou, G.A., Avlessi F., \& Sohounhloué, D.C.K. (2014). Chemical characterization, antiradical and antibacterial activities of extracts of the root bark of Cochlospermum planchoni of Benin. International Journal of Innovation and Applied Studies, 7(4), 1582-1594. http://www.ijias.issr-journals.org/

Mac Donald, I. (2014). Anti-anemic activity of Jatropha tanjorensis Ellis and Saroja in Rabbits. Journal of Medicinal Plants Studies, 2(1), 64-72.

Mapanga, R.F., \& Musabayane, C.T. (2010). The renal effects of blood glucose-lowering plant-derived extracts in diabetes mellitus - an overview. Renal Failure, 32, 132-138. https://doi.org/10.3109/08860220903367585

Nasri, H., \& Shirzad, H. (2013). Toxicity and safety of medicinal plants. Journal of HerbMed Pharmacology, 2(2), $21-22$.

Nwaehujor, C.O. (2015). Effect of Moringa oleifera Lam. Ethanol leaf Extract on Hematology in Phenylhydrazine-induced Anemic Albino Wistar Rats. American Journal of Pharmacological Sciences, 3(3), 67-73. 
O.E.C.D. (2002). Guidelines for the Testing of Chemicals, Section 4. Test No. 423: Acute Oral toxicity - Acute Toxic Class Method Pages: 14. http://dx.doi.org/10.1787/9789264071001

Oduola, T., Popoola, G.B., Avwioro, O.G., Oduola, T.A., Ademosun, A.A., \& Lawal, M.O. (2007). Use of Jatropha gossypifoliastem latex as a haemostatic agent: how safe is it? Journal of Medicinal Plants Research, 1(1), 014-017.

Ogbe, R.J., Adoga, G.I., \& Abu, A.H. (2010). Antianemic potentials of some plant extracts on phenylhydrazine-induced anemia in rabbits. Journal of Medicinal Plants Research, 4, 680-684.

Philomena, G. (2011). Concerns regarding the safety and toxicity of medicinal plants - An overview. Journal of Applied Pharmaceutical Science, 01(6), 40-44.

Pingali, P.S., Srinivasi, P., \& Reddy, M.B. (2015). Study of Anti- Anemic Effect of Schrebera swietenioides Roxb. in rat models. Asian Journal of Pharmaceutical and Clinical Research, 8(5), 260-263. https://doi.org/10.21474/IJAR01/5869

Saxena, M., Mir, A. H., Sharma, M., Malla, M. Y., Qureshi, S., Mir, M. I., \& Chaturvedi, Y. (2013). Phytochemical screening and in-vitro antioxidant activity isolated bioactive compounds from Tridax procumbens Linn. Pak J Biol Sci, 16(24), 1971-1977.

Schmincke, K.H. (2003). Medicinal Plants for forest conservation and healthcare. Non-Wood Forest Products 11. Food and Agriculture Organization of the United Nations. Retrieved from http://www.fao.org/3/a-w7261e.pdf

Senou, M., Khalifa, C., Thimmesch, M., Jouret, F., Devuyst, O., Col, V., ... Gérard, A-C. (2010). A coherent organization of differentiation proteins is required to maintain an appropriate thyroid function in the Pendred thyroid. J. Clin. Endocrinol. Metab., 95(8), 4021-30.

Sènou, M., Tchogou, A.P., Agbangnan, D.C.P., Dougnon, T.V., Ogué, P., Agossadou, A., Lalèyè, A., Loko, F., Agbonon, A. \& Sèzan, A. (2017a). Efficacy of ethyl acetate fraction of Cocos nucifera aqueous extract on the treatment of anemia. International Journal of Pharmaceutical Science Invention, 6(9), 44-51.

Sènou, M., Tchogou, A.P., Assogba, F., Agossadou, A., Dougnon, T.V., Agbangnan, D.C.P., ... Loko, F. (2016). Study of biological tolerance of aqueous extract of Sorghum bicolor. Journal of Applied Biosciences, 109, 10640-10648. http://dx.doi.org/10.4314/jab.v109i1.8

Sènou, M., Tchogou, A.P., Dougnon, T.V., Agbangnan Dossa, C.P., Ogue, P., Agossadou, A., Laleye, A., Loko, F., Agbonon, F., Sezan, A., Baba-Moussa, L. (2017b). Safety of ethyl acetate fraction of Cocos nucifera root extract. International Journal of Advanced Research, 5(11), 1083-1090 http://dx.doi.org/10.21474/IJAR01

Silva, L.C.R., Nunes-Pinheiro, D.C.S., Morais, S.M., Lopes-Neto, B.E., \& Santos, G.J. (2009). Avaliac,ãotoxicological e efeito do extratoacetato de etila da fibra de Cocos nucifera L. (Palmae) sobre a resposta inflamatória in vivo. Rev Bras Plantas Med, 11, 429.

Tchogou, A.P., Sènou, M., Dougnon, T.V., Agossadou, A., Assogba, F., Kinsiclounon, E.G., Ewedjè, E., Agbangnan, D.C.P., Gbénou, J., Lalèyè, A., \& Loko, F. (2016). The Aqueous Extract of Cocos nucifera L. (Arecaceae) Effectively Treat Induced Anemia. Experimental Study on Wistar Rats. International Journal of Biology, 8(3), 1-9. http://dx.doi.org/10.5539/ijb.v8n3p1

Yakubu, M.T., Oladiji, A.T., \& Akanji, M.A. (2009). Mode of cellular toxicity of aqueous extract of Fadogia agresti (Schweinf. Ex Hiern) stem in male rat liver and kidney. Human Exp. Toxicol, 28(8), 469-478. https://doi.org/10.1177\%2F0960327109106973

\section{Copyrights}

Copyright for this article is retained by the author(s), with first publication rights granted to the journal.

This is an open-access article distributed under the terms and conditions of the Creative Commons Attribution license (http://creativecommons.org/licenses/by/4.0/). 